\title{
ASPECTS OF EAFRD PROJECTS IMPLEMENTATION IN ROMANIA DURING 2007-2013 AND 2014-2020
}

\section{Alexandru Sin ${ }^{1}$}

\begin{abstract}
As for all EU member states, EAFRD is an important part of the CAP implementation in Romania. By a comparative study, the present paper analyses some aspects of EAFRD projects, implemented in Romania during 2007-2013 and 2014-2020 programming periods. The analysis was focused on projects addressed to farming and food processing activities, using relevant AFIR reported data.

Investments for agricultural holdings recorded better results during the second period, compared to the first one: a much lower cancelling rate and a higher total value of the projects. However, the increased average value showed a preference for larger farms. More financing opportunities and better consultancy services should be made available to medium farms.

While also presenting a positive improvement, of a significantly decreased cancelling rate, investments for food processing activities also showed a much lower total value. This should be a cause for concern, as insufficient food processing facilities represents one of the main problems of the Romanian agri-food sector. Investments in mentioned sector must be promoted and made a priority in the upcoming 20212027 programming period.
\end{abstract}

Key words: EAFRD, Romania, projects, farming, food processing.

JEL²: O14, Q14, Q18

\section{Introduction}

Since becoming a member of the European Union (EU), Romania has brought its National Rural Development Programme (NRDP) in accordance with the Common Agricultural Policy (CAP). CAP is considered the most important common policy at EU level, with respect to its budget and impact on European citizens, as previous studies highlighted the significant effects agricultural sector has on other sectors of economy (Zaman, 2012).

1 Alexandru Sin, Ph.D. Student, The National Institute for Economic Research "Costin C. Kirițescu" of the Romanian Academy, 13 Septembrie no.13, Bucharest, Romania, Phone: +40 722391 097, E-mail: alxsin@gmail.com

2 Article info: Review Article, Received: $11^{\text {th }}$ August 2020, Accepted: $18^{\text {th }}$ August 2020. 
CAP is structured into the "two pillars", direct payments and market measures, as the first one, and rural development, as the second one (Jongeneel, 2018). Latter is mostly implemented through the European Agricultural Fund for Rural Development (EAFRD). In Romania, EAFRD is implemented by the Agency for Financing Rural Investments (AFIR), (Bumbescu, 2019).

Even if CAP objectives coincide with the concerns of the society, its implementation doesn't always meet people's expectations (Schüler, Noack, 2019). Thus, more targeted measures have to be promoted and adapted to the specific conditions (Cortignani, Dono, 2019). This confirms the need to assess EAFRD implementation's results for each case in particular, as different solutions for improvement might apply to different Member States.

This paper analyses the results of EAFRD projects' implementation in Romania, by a comparative study between the two programming periods: 2007-2013 and 20142020. The research was focused on two financing measures: first one addressed to agricultural holdings (farming activities) and second one addressed to food processing activities.

\section{Materials and Method}

The EU rural development policy, especially in Eastern Europe, remains largely farm-centric (Kiryluk Dryjska et al., 2020). This aspect emphasizes the importance of EAFRD measures aimed at agricultural holdings and value-adding activities. The used research method was based on a quantitative approach, considering the data regarding the number and total value of concluded financing contracts, as well as the number and total value of implemented and under implementation projects, captured by previously mentioned programming periods.

Collected and processed data regarding farming activities corresponded to measure 121 ("Modernization of agricultural holdings"), for the 2007-2013 programming period, and to sub-measure 4.1 ("Support for investments in agricultural holdings"), for the 2014-2020 programming period. Similarly, for food processing activities, measure 123 ("Adding value to agricultural and forestry products"), respectively sub-measure 4.2 ("Support for investments in processing/marketing of agricultural products"), were considered. Even if for the second period (2014-2020) collected data corresponds to the 2014-2019 timeframe, they are relevant for the whole programming period, as there are no other project submission sessions are planned until the end of 2020, except very specific and targeted actions (e.g. investments in slaughterhouses in mountain areas). However, the budget assigned to these actions is rather low compared to the total available funds for the period. 
For each measure/sub-measure and each programming period, based on data reported by AFIR, the "cancelling rate" index, as well as the average value of implemented and under implementation projects, were calculated. The cancelling rate index was calculated as the rate of the total value of cancelled financing contracts from the total value of concluded financing contracts.

\section{Research and Results}

A previous Input - Output analysis, focused on CAP, found that the implementation of Pillar II measures, especially investments in the agri-food sector, had a positive impact on the regional economy, both on its output and income levels (Lampiris et al., 2018). Also, the second pillar has an important impact not only on agri-food production, but also on the European society as a whole. It was estimated that a $10 \%$ increase of the CAP budget generates a decrease of more than 15,000 persons in the total number of people leaving the agriculture sector each year (Garrone et al., 2019).

For Romania, each of the measures 121 and 123 had budgets of over $10 \%$ of the total EAFRD 2007-2013 budget, by far the largest budgets addressed to the private sector. For the next programming period, 2014-2020, their shares within the EAFRD budget, remained mostly unchanged, both corresponding sub-measures, 4.1 and 4.2, cumulatively adding up to more than $20 \%$ of the total budget.

Analysing the data regarding EAFRD investment projects for agricultural holdings, the results lead to different conclusions between these two programming periods. Despite the fact that number of concluded financing contracts has presented only a slight variation $(+7.36 \%)$, the number of implemented and under implementation projects has an almost 21\% higher value for the 2014-2020 programming period, compared to the previous one (Table 1.). Also, the total values of concluded financing contracts, and implemented and under implementation projects has been significantly higher for the 2014-2020 period compared to the 2007-2013 period (for $34.64 \%$ and $58.63 \%$ respectively).

The average value of implemented and under implementation projects was more than $30 \%$ higher for sub-measure 4.1 compared to measure 121 . As seen, during the second period, implemented projects had bigger budgets, promoting larger investments, channelled to large farms. This means that less medium size farms accessed EAFRD funding, one of the reasons being the obstacles this type of farms faced in securing the co-financing part. This was the reason for the high cancelling rate during the first programming period. The subject of small farms has not been addressed within this research, as their investments were covered by a separate (specific) sub-measure. 
Previous researches found the cancelling rate to be of an alarming level for the 2007-2013 programming period, and one of the most important causes of drawback regarding EU funds absorption, for both Measure 121 and Measure 123. Basically, mostly because of lack of private funds, necessary for the co-financing part, a large number of financing contracts had to be cancelled because the projects could not be implemented (Sin, 2014).

Table 1. Implementation results of EAFRD measures for agricultural holdings (measure 121 and sub-measure 4.1)

\begin{tabular}{|c|l|r|r|c|}
\hline \multirow{2}{*}{$\#$} & \multicolumn{1}{|c|}{ EAFRD projects } & \multicolumn{2}{c|}{ Programming period } & \multirow{2}{*}{$\begin{array}{c}\text { Variation rate } \\
\text { (+/- \%) }\end{array}$} \\
\cline { 3 - 4 } & \multicolumn{2}{|c|}{$\mathbf{2 0 0 7 - 2 0 1 3}$} & $\mathbf{2 0 1 4 - 2 0 2 0}$ & \\
\hline $\mathbf{1}$ & Number of projects & 2,254 & 2,420 & $\mathbf{7 . 3 6 \%}$ \\
\hline $\mathbf{1 . 1}$ & Concluded financing contracts & 1,963 & 2,374 & $\mathbf{2 0 . 9 4 \%}$ \\
\hline $\mathbf{1 . 2}$ & $\begin{array}{l}\text { Implemented and under implementation } \\
\text { projects }\end{array}$ & 886,727 & $1,193,888$ & $\mathbf{3 4 . 6 4 \%}$ \\
\hline $\mathbf{2}$ & Total value of projects (thousand EUR) & 734,659 & $1,165,361$ & $\mathbf{5 8 . 6 3 \%}$ \\
\hline $\mathbf{2 . 1}$ & Concluded financing contracts & $17.15 \%$ & $2.39 \%$ & $\mathbf{- 8 6 . 0 7 \%}$ \\
\hline $\mathbf{2 . 2}$ & $\begin{array}{l}\text { Implemented and under implementation } \\
\text { projects }\end{array}$ & 374,253 & 490,885 & $\mathbf{3 1 . 1 6 \%}$ \\
\hline $\mathbf{3}$ & Cancelling rate & $\begin{array}{l}\text { Average value of implemented and under } \\
\text { implementation projects (EUR) }\end{array}$ & &
\end{tabular}

Source: Authors' calculations based on AFIR data (AFIR, 2019; AFIR, 2020).

Other reasons were linked to insufficient available consulting and advisory services. Consultants preferred to limit their services to the project submission phase, not providing the much needed implementation consultancy. The consultants' involvement in the implementation stage of the projects is a measure of their level of professionalism first of all, but also of the degree of knowledge and awareness of their clients (Kubr, 1992). So, the lack of beneficiaries' know-how and unrealistic assumptions regarding the complexity of the implementation process also contributed to the high cancelling rate of approved projects.

This situation is significantly improved during the $2014-2020$ programming period, as the cancelling rate dropped by a rate of $86 \%$, from $17.15 \%$ to $2.39 \%$ for investments in farming activities, and by $82 \%$, from $24.65 \%$ to $4.44 \%$ for investments in food processing activities (Table 1. and Table 2.). 
Table 2. Implementation results of EAFRD measures for agricultural holdings (measure 123 and sub-measure 4.2)

\begin{tabular}{|c|c|c|c|c|}
\hline \multirow{2}{*}{ \# } & \multirow{2}{*}{ EAFRD projects } & \multicolumn{2}{|c|}{ Programming period } & \multirow{2}{*}{$\begin{array}{c}\text { Variation } \\
\text { rate }(+/-\%)\end{array}$} \\
\hline & & $2007-2013$ & 2014-2020 & \\
\hline 1 & \multicolumn{4}{|l|}{ Number of projects } \\
\hline 1.1 & Concluded financing contracts & 1,290 & 559 & $-56.67 \%$ \\
\hline 1.2 & $\begin{array}{l}\text { Implemented projects and projects under } \\
\text { implementation }\end{array}$ & 991 & 538 & $-45.71 \%$ \\
\hline 2 & \multicolumn{4}{|l|}{ Total value of projects (thousand EUR) } \\
\hline 2.1 & Concluded financing contracts & $1,007,704$ & 375,150 & $-62.77 \%$ \\
\hline 2.2 & $\begin{array}{l}\text { Implemented projects and projects under } \\
\text { implementation }\end{array}$ & 759,350 & 358,508 & $-52.79 \%$ \\
\hline 3 & Cancelling rate & $24.65 \%$ & $4.44 \%$ & $-82 \%$ \\
\hline 4 & $\begin{array}{l}\text { Average value of implemented and } \\
\text { under implementation projects (EUR) }\end{array}$ & 766,246 & 666,372 & $-13 \%$ \\
\hline
\end{tabular}

Source: Authors' calculations based on AFIR data (AFIR, 2019; AFIR, 2020).

Contrary to what happened to the investments in farming activities, the number and the total value of projects aimed at food processing activities dropped during the second analysed period, by rates between $45.71 \%$, for the number of implemented and under implementation projects, and $62.77 \%$, for the total value of concluded financing contracts. The average value of implemented and under implementation projects was also lower, by $13 \%$, during the $2014-2020$ programming period, compared to the previous one.

When comparing the evolution of the two types of investment actions, for farming and for food processing, it could be noticed the two different trends: while the total value of investments in farming increased in the second programming period, the total value of investments in food processing decreased (Figure 1.).

If the first trend signifies a positive interest of the beneficiaries in the modernization of the agricultural holdings by the acquisition of new agricultural machinery, which will lead to more efficient activities by lower production costs and higher productivity, the second trend should cause concern. Decrease in new investments in the food processing sector means a slowdown of the expansion and modernization of added value activities. The main problem of Romanian agriculture is the low level of efficiency within the entire agri-food sector (Alecu, Cazac, 2020). NRDPs for both programming periods showed the existing focus on agricultural production of raw materials and insufficient processing facilities (MADR, 2015; MADR, 2020). Thus, the shown trend doesn't represent a step in the right direction. 
Figure 1. Total value of implemented and under implementation EAFRD projects (in thousand EUR)

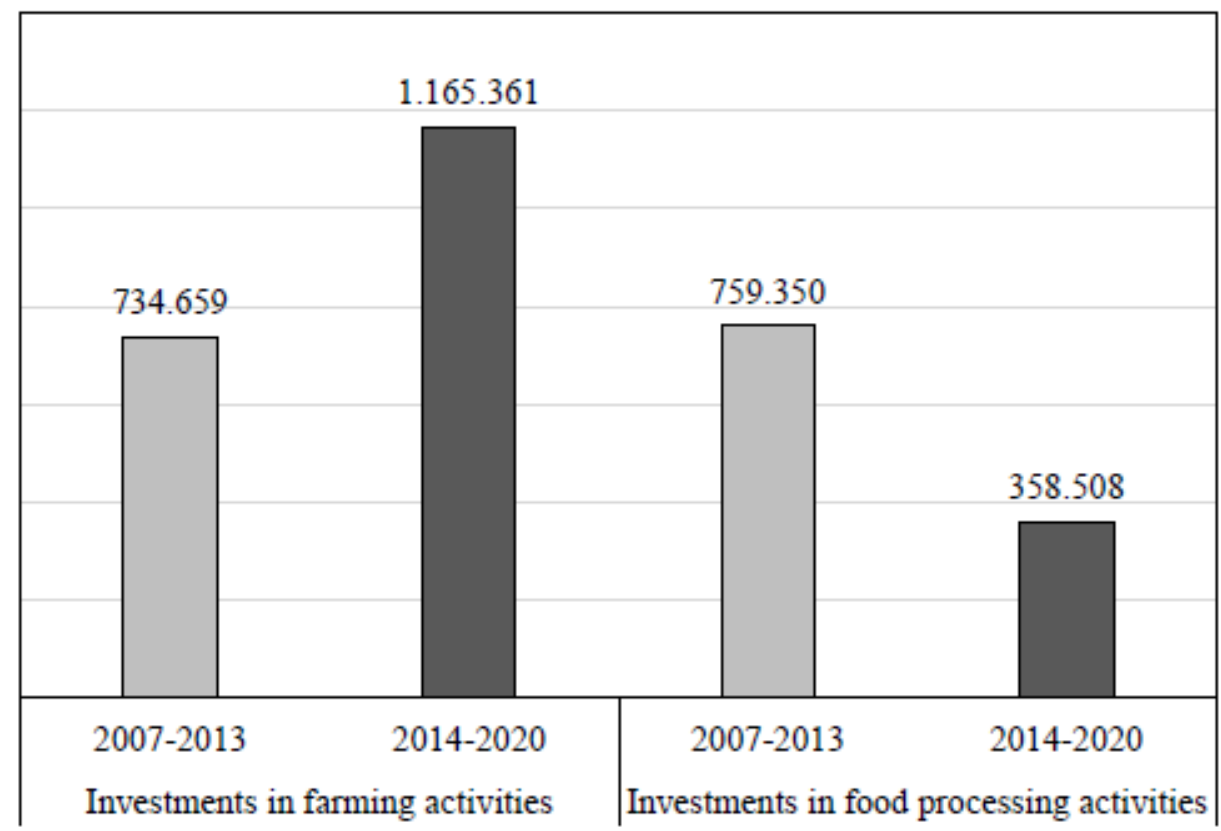

Source: Authors' calculations based on AFIR data (AFIR, 2019; AFIR, 2020).

\section{Conclusions}

When comparing the results between 2007-2013 and 2014-2020 programming period, several important improvements were made.

Firstly, and maybe the most important, the rate of the cancelled financing contract dropped significantly, with more than $80 \%$, for the both analysed measures: investments for agricultural holdings and investments for food processing activities.

Secondly, the total value of investments in agriculture has a significant increase, for almost $60 \%$, partially linked to the low rate of cancelled projects.

Thirdly, the average value of investment projects in agriculture also increased, by more than $30 \%$, showing a preponderance of large farms among beneficiaries.

The smaller number of medium size farms accessing EU financing, during the second period, was partially caused by the difficulties for these farms in accessing the private funds necessary for co-financing EAFRD projects. 
This was also the main reason for the high cancelling rate during the 2007-2013 programming period. New and more adapted financing mechanisms need to be identified and implemented, to ensure medium size farms' access to finance.

Fourthly, the total value of investments in food processing decreased, with over 50\%. This represents a drawback, as insufficient processing capacity is one of the major problems of the Romanian agriculture. Adding value to agricultural production is essential for a competitive and efficient agri-food sector. Investments in this area should be promoted by offering incentives for building new facilities, expanding existing ones and integrating processing into farm activities. This should represent a priority for the following 2021-2027 programming period.

\section{References}

1. AFIR (2019). Raport AFIR privind stadiul Proiectelor PNDR 2007-2013 la data de 06.10.2016. Agency for Financing Rural Investments (AFIR), Bucharest, Romania, available at: $\underline{w w w . a f i r . i n f o /, ~ r e t r i e v e d ~ a t: ~ 25.11 .2019 . ~}$

2. AFIR (2020). Raport AFIR de implementare a PNDR 2014-2020 la data de 31.12.2019. Agency for Financing Rural Investments (AFIR), Bucharest, Romania, available at: www.afir.info/, retrieved at: 07.05.2020.

3. Alecu, I. N., Cazac V. (2020). Managementul agricol în România. Editura Ceres, Bucharest, Romania.

4. Bumbescu, S. S. (2019). Agency for Financing Rural Investments: The Agency Which Manages Funds from Pillar II of Common Agricultural Policy. Ovidius University Annals, Economic Sciences Series, 19(2):199-204.

5. Cortignani, R., Dono, G. (2019). CAP's environmental policy and land use in arable farms: An impacts assessment of greening practices changes in Italy. Science of the Total Environment, 647:516-524.

6. Garrone, M., Emmers, D., Olper, A., Swinnen, J. (2019). Jobs and agricultural policy: Impact of the common agricultural policy on EU agricultural employment. Food Policy, 87: article no. 101744.

7. Jongeneel R. A. (2018). Research for AGRI Committee - The CAP support beyond 2020: assessing the future structure of direct payments and the rural developments interventions in the light of the EU agricultural and environmental challenges, European Parliament, Policy Department for Structural and Cohesion Policies, Brussels, Belgium. 
8. Kiryluk Dryjska, E., Beba, P., Poczta, W. (2020). Local determinants of the Common Agricultural Policy rural development funds' distribution in Poland and their spatial implications. Journal of Rural Studies, 74:201-209.

9. Kubr, M. (1992). Management consulting. AMCOR, Bucharest, Romania.

10. Lampiris, G., Karelakis, C., Loizou, E. (2018). Evaluation of the impacts of CAP policy measures on a local economy: The case of a Greek region. Land Use Policy, 77:745-751.

11. MADR (2015). Programul Național de Dezvoltare Rurală pentru perioada 2007-2013 (version September 2015). Ministerului Agriculturii și Dezvoltării Rurale (MADR), Bucharest, Romania.

12. MADR (2020). Programul Național de Dezvoltare Rurală pentru perioada 2014-2020 (version X). Ministerului Agriculturii și Dezvoltării Rurale (MADR), Bucharest, Romania.

13. Schüler, S., Noack, E. M. (2019). Does the CAP reflect the population's concerns about agricultural landscapes? A qualitative study in Lower Saxony, Germany. Land Use Policy, 83:240-255.

14. Sin, A. (2014). Dezvoltarea rurală și implementarea PNDR 2007-2013 în România. Analiză comparativă România-Polonia. Editura Terra Nostra, Iași, Romania.

15. Zaman, G. (2012). Challenges and requirements for sustainable development of Romania's agriculture based on the input-output analysis. Romanian Journal of Economics, 35(2/44):4-15. 